\title{
Mice models of NAFLD-related HCC
}

\author{
Anna Chen, Anqian Lu and Jin Yang* \\ Translational Medicine Center, The Affiliated Hospital of Hangzhou Normal University, China
}

\begin{abstract}
Nonalcoholic fatty liver disease (NAFLD)-related hepatocellular carcinoma (HCC) shows growing tendency across the world, thus requiring the convenient mice models mimic the pathology and pathogenesis of human disease to accelerate the findings of this disease. Herein, we summarized the mice model of NAFLD-HCC recently developed.
\end{abstract}

An ideal mice model must meet the following factors. 1) The natural history of NAFLD progress, from NAFLD, nonalcoholic steatohepatitis (NASH), to the end-stage of the disease. 2) The pathology concordance with human NAFLD, including steatosis, ballooning, lobular inflammation, fibrosis stage and nodule formation. 3) Other factors such as modelling period, and possible pathogenesis should be taken into consideration. Here, we summarized the models in Table 1.
In total, mouse genotype, diet and chemical inducer constitute the main strategies for developing NAFLD-HCC model, therefore the combination of these factors is also a widely-used method, such as $\mathrm{db} / \mathrm{db}$ mice supplemented with iron [3], and melanocortin 4 receptor-deficient mice (MC4R-KO) fed a high-fat diet [14], which aims at the specific pathogenesis of the disease. Indeed, different model combination is an option for the preclinical study due to the heterogenesis of the disease.

Table 1: Mice models of NAFLD-HCC

\begin{tabular}{|c|c|c|c|}
\hline Model & Feature and Advantages & Disadvantages & Reference \\
\hline \multicolumn{4}{|c|}{ Diet-and chemical-induced } \\
\hline $\begin{array}{l}\mathrm{WD} / \\
\mathrm{CCL}_{4}\end{array}$ & $\begin{array}{l}\text { A western diet combined with low weekly dose of } \mathrm{CCl}_{4} \text { injections. } \\
\text { Western Diet (WD): high-fat, high-fructose and high-Cholesterol. } \\
\text { The key metabolic and histologic features of human NASH appeared within } \\
12 \text { weeks, and result in HCC development at } 24 \text { weeks. } \\
\text { The model closely replicates transcriptomic hallmarks of human NASH. }\end{array}$ & $\begin{array}{l}\text { Severe NASH and fibrosis are not fully induced even after } \\
\text { long-term feeding. } \\
\mathrm{CCL}_{4} \text { is poisonous to animals, and can induce DNA } \\
\text { damage. } \\
\text { Cholesterol absorption in mice is much less efficient than } \\
\text { in humans. }\end{array}$ & $\begin{array}{l}{[1]} \\
{[2]}\end{array}$ \\
\hline STAM & $\begin{array}{l}\text { Mice treat with Streptozotocin (STZ) shortly after birth, then fed a high fat } \\
\text { diet (HFD). } \\
\text { Develop NASH, fibrosis and HCC after } 8,16 \text { and } 20 \text { weeks of HFD, } \\
\text { respectively. }\end{array}$ & $\begin{array}{l}\text { Develop type } 1 \text { diabetes due to a lack of insulin rather than } \\
\text { through insulin resistance (IR). }\end{array}$ & $\begin{array}{l}{[1]} \\
{[3]} \\
{[4]} \\
{[5]}\end{array}$ \\
\hline DIAMOND & $\begin{array}{l}\text { Based on an isogenic strain of C57BL/6J (B6) and 129S1/SvImJ (S129), fed a } \\
\text { HFD with glucose-fructose in drinking water. } \\
\text { Mice develop steatosis, IR within } 16 \text { weeks, and nodule formation by } 52 \\
\text { weeks. } \\
\text { A strong concordance with the human NAFLD transcriptome. }\end{array}$ & $\begin{array}{l}\text { Suppression of cholesterol synthesis. } \\
\text { A longer time to achieve the NASH standard. } \\
\text { Genetic background of DIAMOND mice is unique, making } \\
\text { it difficult to cross them with other gene targeted mice. }\end{array}$ & $\begin{array}{l}{[1]} \\
{[3]} \\
{[4]} \\
{[6]} \\
{[7]}\end{array}$ \\
\hline $\begin{array}{l}\text { CDA } \\
/ \mathrm{HFD}\end{array}$ & $\begin{array}{l}\text { A choline-deficient, L-amino acid-defined, high-fat diet, without individual } \\
\text { difference and loss of weight, is another amelioration of MCD (Methionine-/ } \\
\text { Choline-Deficient). NASH pathology develops at } 3 \text { weeks, and continue to } \\
\text { develop HCC from } 36 \text { weeks until } 60 \text { weeks without carcinogenesis in any } \\
\text { other organ. } \\
\text { Histological changes were similar to human NASH, also this progression } \\
\text { would not affect adiposity or insulin sensitivity. }\end{array}$ & $\begin{array}{l}\text { The low penetrance of HCC induction. } \\
\text { Lack of information related factors that distinguish the mice } \\
\text { that evolve to HCC from the tumor-free mice. }\end{array}$ & $\begin{array}{l}{[4]} \\
{[8]}\end{array}$ \\
\hline
\end{tabular}

${ }^{\star}$ Correspondence to: Jin Yang, Translational Medicine Center, The Affiliated Hospital of Hangzhou Normal University, Hangzhou, Zhejiang, 310015, China, E-mail: hz_zhiy@163.com

Key words: NAFLD, HCC, model

Received: July 25, 2019; Accepted: August 10, 2019; Published: August 12, 2019 


\begin{tabular}{|c|c|c|c|}
\hline $\mathrm{FFC}$ & $\begin{array}{l}\text { The high fat, fructose and cholesterol diet, include features of the metabolic } \\
\text { syndrome and efficiently causes hepatic steatosis, steatohepatitis and fibrosis. }\end{array}$ & $\begin{array}{l}\text { The mice does not continue to evolve advanced fibrosis or } \\
\text { HCC. }\end{array}$ & $\begin{array}{l}{[1]} \\
{[3]}\end{array}$ \\
\hline ALIOS & $\begin{array}{l}\text { Mice fed a high-fat/fructose diet with sedentary lifestyle, produces features of } \\
\text { early human NASH at } 6 \text { months. } \\
\text { The genes were increased in hepatic expression of lipid metabolism and } \\
\text { insulin signaling. }\end{array}$ & $\begin{array}{l}\text { Differences between mice and human histopathology were } \\
\text { observed in the pattern and distribution of steatosis, fibrosis } \\
\text { and cell proliferation. } \\
\text { HCC develop only after } 12 \text { months of feeding. }\end{array}$ & {$[9]$} \\
\hline $\mathrm{HFCD} / \mathrm{DEN}$ & $\begin{array}{l}\text { a high-fat, choline-deficient (HFCD) diet with injection of diethylnitrosamine } \\
\text { (DEN), the time to HCC development is } 20 \text { weeks. }\end{array}$ & $\begin{array}{l}\text { The HCC initiation is mainly dependent on DEN (a kind of } \\
\text { chemcial carcinogens). }\end{array}$ & {$[5]$} \\
\hline \multicolumn{4}{|c|}{ Genetic manipulations } \\
\hline $\begin{array}{l}\text { MUP- } \\
\text { uPA }\end{array}$ & $\begin{array}{l}\text { Based on feeding HFD to MUP-uPA transgenic mice. The mice develop } \\
\text { NASH with up to } 85 \% \text { of them progressing to HCC. Making a distinction } \\
\text { between the mice that develop tumors and those that do not through } \\
\text { monitoring and following the mice at the start of NASH, which enables } \\
\text { biomarker discovery and discrimination of molecular drivers of HCC } \\
\text { development. }\end{array}$ & $\begin{array}{l}\text { The development of } \mathrm{HCC} \text { is slow. } \\
\text { The mutational landscape varies from mice to mice, this } \\
\text { heterogeneity make the drug progression more complicate. }\end{array}$ & {$[4]$} \\
\hline $\begin{array}{l}\text { PTEN knock- } \\
\quad \text { out }\end{array}$ & $\begin{array}{l}\text { PTEN is a tumor suppressor gene, which spontaneously progress to } \\
\text { steatohepatitis, with histologic features of human NASH. }\end{array}$ & $\begin{array}{l}\text { Insulin hypersensitivity and lessened fat are contrary to the } \\
\text { human NASH. } \\
\text { Compared to males, the liver lesion in mice were weaken in } \\
\text { females, were similar to human disease, thus sex difference } \\
\text { should be considered. }\end{array}$ & $\begin{array}{l}{[5]} \\
{[10]} \\
{[11]} \\
{[12]}\end{array}$ \\
\hline $\mathrm{ob} / \mathrm{ob} \mathrm{db} / \mathrm{db}$ & $\begin{array}{l}\text { The Leptin-deficien mice. } \\
\text { ob/ob mice are diabetic owing to the deficiency of leptin gene and genetically } \\
\text { obese. } \\
\text { db/db mice have a defective leptin receptor gene. } \\
\text { That exhibits human matabolic syndrome. }\end{array}$ & $\begin{array}{l}\text { No matter in the obese humans or NASH patients, it is not } \\
\text { prevalent to congenital leptin deficiency or leptin resistance } \\
\text { caused by gene mutations. } \\
\text { Both ob/ob and db/db mice need extra stimulator to make } \\
\text { NASH develop HCC, but even though treating with the } \\
\text { carcinogen diethylnitrosamine, which is still more possible } \\
\text { to induce HCC directly, not go through NASH. }\end{array}$ & $\begin{array}{l}{[3]} \\
{[5]} \\
{[11]} \\
{[13]}\end{array}$ \\
\hline $\begin{array}{l}\text { foz/ } \\
\text { foz }\end{array}$ & $\begin{array}{l}\text { The obese mice, which carry a mutated Alms } 1 \text { gene and may play a vital role } \\
\text { in appetite regulation. } \\
\text { Develop hepatic steatosis, obesity, diabetes, and IR, show significant } \\
\text { upregulation of cholesterol levels. }\end{array}$ & The severity of NASH is dependent on mice strain. & $\begin{array}{l}{[3]} \\
{[12]} \\
{[13]}\end{array}$ \\
\hline
\end{tabular}

\section{References}

1. Castro RE, Diehl AM (2018) Towards a definite mouse model of NAFLD. J Hepatol 69: 272-274. [Crossref]

2. Tsuchida T, Lee YA, Fujiwara N, Ybanez M, Allen B, et al. (2018) A simple diet- and chemical-induced murine NASH model with rapid progression of steatohepatitis, fibrosis and liver cancer. J Hepatol 69: 385-395. [Crossref]

3. Santhekadur PK, Kumar DP, Sanyal AJ (2018) Preclinical models of non-alcoholic fatty liver disease. $J$ Hepatol 68: 230-237. [Crossref]

4. Febbraio MA, Reibe S, Shalapour S, Ooi GJ, Watt MJ, et al. (2019) Preclinical Models for Studying NASH-Driven HCC: How Useful Are They? Cell Metab 29: 18-26. [Crossref]

5. Kishida N, Matsuda S, Itano O, Shinoda M, Kitago M, et al. (2016) Development of a novel mouse model of hepatocellular carcinoma with nonalcoholic steatohepatitis using a high-fat, choline-deficient diet and intraperitoneal injection of diethylnitrosamine. BMC Gastroenterol 16: 61. [Crossref]

6. Oseini AM, Cole BK, Issa D, Feaver RE, Sanyal AJ (2018) Translating scientific discovery: the need for preclinical models of nonalcoholic steatohepatitis. Hepatol Int 12: 6-16. [Crossref]

7. Asgharpour A, Cazanave SC, Pacana T, Seneshaw M, Vincent R, et al. (2016) A dietinduced animal model of non-alcoholic fatty liver disease and hepatocellular cancer. $J$ Hepatol 65: 579-588. [Crossref]
8. Ikawa-Yoshida A, Matsuo S, Kato A, Ohmori Y, Higashida A, et al. (2017) Hepatocellular carcinoma in a mouse model fed a choline-deficient, L-amino aciddefined, high-fat diet. Int J Exp Pathol 98: 221-233. [Crossref]

9. Dowman JK, Hopkins LJ, Reynolds GM, Nikolaou N, Armstrong MJ, et al. (2014) Development of hepatocellular carcinoma in a murine model of nonalcoholic steatohepatitis induced by use of a high-fat/fructose diet and sedentary lifestyle. $\mathrm{Am} \mathrm{J}$ Pathol 184: 1550-1561 [Crossref]

10. Anezaki Y, Ohshima S, Ishii H, Kinoshita N, Dohmen T, et al. (2009) Sex difference in the liver of hepatocyte-specific Pten-deficient mice: A model of nonalcoholic steatohepatitis. Hepatol Res 39: 609-618. [Crossref]

11. Ibrahim SH, Hirsova P, Malhi H, Gores GJ (2016) Animal Models of Nonalcoholic Steatohepatitis: Eat, Delete, and Inflame. Dig Dis Sci 61: 1325-1336. [Crossref]

12. Lau JK, Zhang X, Yu J (2017) Animal models of non-alcoholic fatty liver disease: current perspectives and recent advances. $J$ Pathol 241: 36-44. [Crossref]

13. Jiang M, Wu N, Chen X, Wang W, Chu Y, et al. (2019) Pathogenesis of and major animal models used for nonalcoholic fatty liver disease. J Int Med Res 47: 1453-1466. [Crossref]

14. Itoh M, Suganami T, Nakagawa N, Tanaka M, Yamamoto Y, et al. (2011) Melanocortin 4 receptor-deficient mice as a novel mouse model of nonalcoholic steatohepatitis. $\mathrm{Am} \mathrm{J}$ Pathol 179: 2454-2463. [Crossref]

Copyright: (C2019 Chen A. This is an open-access article distributed under the terms of the Creative Commons Attribution License, which permits unrestricted use, distribution, and reproduction in any medium, provided the original author and source are credited. 